The relationship between social support coverage and well-being was examined in four subgroups from a national sample of women ages 50 and older: first married $(N=151)$, widows $(N=144)$, widows within the last five years $(n=60)$, and widows for longer than five years $(n=84)$. The index of support coverage represented how many of six functions were carried out by at least one supporter. Two hypotheses were tested: (1) that support coverage is associated with well-being in all subgroups, and (2) that social support is more strongly associated with well-being in the subgroups experiencing higher stress, that is, widows more than married women and recent widows more than long-term ones. The hypotheses were not supported. Instead, the relationships between social support and well-being were positive in some groups and negative in others. The importance of considering the causal directions of links between social support and well-being and the possible negative consequences of receiving social support are discussed.

\title{
Social Support Coverage and the Well-Being of Elderly Widows and Married Women*
}

\author{
RITSUKO WATANABE GREENE \\ SHEILA FELD \\ University of Michigan
}

By the age 65, more than $50 \%$ of American married women become widows (Heinemann, 1983). Diverse evidence shows that in comparison to married women widows experience lower morale (Fengler, Danigelis, and Grams, 1982; Veroff, Douvan, and Kulka, 1981) and a higher incidence of mental problems (Thompson, Gallagher, Breckenridge, and Peterson, 1984). Given widowhood's prevalence and negative consequences, it is important to clarify the factors that affect the well-being of elderly widows.

Social support is widely recognized as important for the well-being of widows. A husband's death often deprives the widow of her main

\footnotetext{
*We would like to express our appreciation to Robert Kahn and Toni Antonucci, who allowed us to use their data and provided useful suggestions, and to Hiroko Akiyama, Joseph Veroff, and anonymous reviewers who provided valuable comments on an earlier version of this manuscript. Requests for reprints should be sent to Sheila Feld, School of Social Work, University of Michigan, Ann Arbor, MI 48106.
}

JOURNAL OF FAMILY ISSUES, Vol. 10 No. 1, March 1989 33-51

๑) 1989 Sage Publications, Inc. 
social supporter, and the grief and other stress created by widowhood enhance the need for social support (Stroebe and Stroebe, 1987). There is evidence that widows who have or perceive more support are less distressed than are widows with less support (Bock and Webber, 1972; Dimond, Lund, and Caserta, 1987; Morgan, 1976; Pilisuk and Minkler, 1980; Vachon et al., 1982). Social support may also be important for many older persons because of declining health and other chronic strains associated with aging. What is not clear from earlier research is whether social support functions in distinctive ways for older widows or is more important for them than it is for other older women. This study addresses this issue by comparing the relationship between social support and well-being in a representative national sample of elderly widows and married women.

Furthermore, we use recent advances in the conceptualization of the relationships among stress, social support, and distress and in the conceptualization and measurement of social support, much of which have not been considered in the study of bereavement (Bankoff, 1983). One important question about how social support may benefit well-being is whether it has a generalized beneficial effect regardless of the amount of stress experienced or whether support acts as a buffer between the stress-distress linkage, protecting those persons experiencing stress from distress. These have been termed the main and interactive effects of support (Cohen and Wills, 1985). One way of addressing this issue is to compare the estimated effects of social support in groups that differ in stress, as between widows and married women (Stroebe and Stroebe, 1987). Another way is to compare the estimated effects of social support among widows who differ in their levels of stress and strain. This is valuable because married women and widows differ not only in their amount of stress and chronic strain, but also in the presence of a spouse in their social support network. As recency of widowhood is a good proxy for the amount of grief and situational problems being experienced (Morgan, 1984), we will also compare the relationship between social support and distress in recent and longer-term widows.

If support has a generalized beneficial main effect on the well-being of older women, social support should be positively related to wellbeing in all subgroups. If support only has a buffering effect, social support should be positively related to well-being only among the more stressed subgroups. If support has both a buffering and main effect, social support should be related to positive well-being in all the 
subgroups and that relationship should be stronger in the more stressed subgroups, namely, widows more than married women and recent widows more than long-term widows. On the basis of prior research (Cohen and Hoberman, 1983), we expected social support to have both a generalized beneficial main effect and a buffering effect.

The conceptualization and measurement of social support in the present study was based on three trends in theory and research. First, we were interested in subjective judgments of the availability of social support because judgments of adequacy have been shown: (1) to be better predictors of elderly respondents' well-being than are social network variables, such as size or density of network (Kahn and Antonucci, 1985); and (2) to moderate the effects of objective indicators of social integration on well-being (Liang, Dvorkin, Kahana, and Mazian, 1980). Second, we defined adequacy of social support in terms of the number of functions covered by available supporters because social support is acknowledged to have multiple functions for well-being (Kahn and Antonucci, 1985; Lopata, 1979). And finally, we viewed a function as being adequately covered if just one person provided that type of support because of evidence that under some circumstances well-being can be maintained when there is only one person on whom one can depend and share confidences (Arling, 1987; Kessler, Price, and Wortman, 1985; Lowenthal and Havens, 1968).

The final issue to be addressed in studying the role of adequacy of social support in the stress process is what is meant by well-being, an issue about which there is little consensus (Stull, 1987). Consistent with most research on stress and social support we focused on the emotional components of well-being. Unlike some researchers, however, we were interested in the possible effects of social support on both negative and positive emotional states.

In sum, this study concerns the relationship between social support and positive and negative aspects of well-being in four subgroups of older women drawn from a representative national sample. Two hypotheses were tested: (1) that more complete social support coverage would have a generalized beneficial main effect on wellbeing, being associated with less distress and with positive emotions in all subgroups, and (2) that social support coverage would act as a buffer in the relationship between stress and well-being, resulting in social support coverage being more strongly related to less distress and to positive emotions among widows than among married 
women, and among more recent as compared with long-term widows.

\section{METHODS}

\section{SUBJECTS AND INTERVIEW CONTEXT}

Subjects were drawn from the 1980 Social Networks in Adult Life study, a nationwide survey of 718 community-residing adults 50 years of age or older selected by a random multistage probability sample of households that oversampled individuals aged 70 and older (Kahn and Antonucci, 1985). Ss were interviewed in their homes by trained survey interviewers using a standard questionnaire. The response rate was $73 \%$.

The present study is a secondary analysis based on all women who were widowed at age 50 or later $(N=144)$ or who were in their first marriages $(N=151)$ and who had complete data on relevant variables. The widows were divided into two categories: recent widows, that is, those who became widows in the last five years $(n=60)$; and long-term widows, that is, those widowed for longer than five years $(n=84)$. The mean years of widowhood for the total group, the recent widows, and long-term widows, was $9.45,3.12$ and 13.68 , respectively.

\section{MEASUREMENT OF PERCEIVED SOCIAL SUPPORT COVERAGE}

Respondents were first queried about the important members of their personal networks and then were asked which network members provided each of six types of support: “. . . people you confide in about things that are important to you? ... who reassure you when you are feeling uncertain about something? . . . who make you feel respected? . . . who you talk to when you are upset, nervous, or depressed? ... who would make sure that you were cared for if you were ill? . . . who you talk to about your health?"

The questions reflected the three functions that have been proposed for social support-emotional, respect, and health-related support (Kahn and Antonucci, 1985; Kohen, 1983; Lopata, 1979). Emotional support is emphasized because instrumental and material aid seem to have more specific, short-term effects (House and Kahn, 1985; Turner, 1983). 
The index of Social Support Coverage was the number of the six functions for which one or more social supporters were mentioned. This approach assumes that the extent to which this set of functions is covered would affect the well-being of the elderly; the presence of one supporter for any area would be sufficient to have a positive impact on well-being; and which person carried out the functions was not critical. If these assumptions are correct, the index would be an indirect estimate of the adequacy of social support that is not methodologically confounded with the measurement of well-being. Prior research has suffered from such confounding because questions measuring well-being (e.g., depressive symptoms, happiness) often had overlapping content with those measuring adequacy of the support network (e.g., satisfaction with family or friends) and because judgments of adequacy of social support may themselves be manifestations of distress (Arling, 1987).

This social support coverage index yielded scores from 0 to 6 and had a Cronbach's alpha of .74 , indicating the appropriateness of summing these six functions. Because very few $S$ s had scores of 0 to 3, the variable was recoded into 4 levels with the following distribution: Level $1($ Coverage $0-3)=21(7.1 \%) ;$ Level $2($ Coverage 4$)=30(10.2 \%)$; Level $3($ Coverage 5$)=68(23.1 \%)$; Level $4($ Coverage 6$)=176(59.7 \%)$. Thus slightly more than $50 \%$ of all $S \mathrm{~s}$ had at least one supporter for all functions, whereas less than $10 \%$ had coverage for half or fewer of the functions. $(M=3.35$ and $S D=.93$. $)$

\section{MEASUREMENT OF DEPENDENT VARIABLES}

Three variables that have been shown to be independent components of well-being were used to measure well-being (Stull, 1987). Happiness was measured by responses to the question. "Taking all things together, how would you say things are these days ... would you say you are very happy, pretty happy, or not too happy?" Replies were coded 1 to 3 from low to high. $(M=2.16$ and $S D=.60$.)

Both positive and negative affect were measured by five questions from the Bradburn Affect Balance Scale (Bradburn, 1969) that ask about experiences during the past few weeks. The negative affect items concerned restlessness, loneliness, boredom, depression, and upset at criticism. The positive affect items described excitement, pride, pleasure in accomplishments, being on top of the world, and things going your way. Affirmative replies were summed to yield two variables ranging from 1 (no negative or no positive affects) to 6 (five 
negative or five positive affects). $M=2.22, S D=1.45$, and Cronbach's alpha $=.69$ for negative affect; $M=3.96, S D=1.48$, and alpha $=.60$ for positive affect.

\section{MEASUREMENT OF CONTROL VARIABLES}

Additional variables were included to control for differences between widows and married women, and between recent and longerterm widows that might be related to well-being. Prior evidence suggested that stressful life events, health status, income, and age should be controlled (Larson, 1978; Whitbourne, 1985).

The measure of life events was based on 12 items Kahn and Antonucci (1985) had adapted from Holmes and Rahe (1967): divorced or separated; death of spouse; death of close family member or friend; illness of family member; immediate family member in nursing home; child left home; changed place of residence; change in financial status; spouse fired, laid off, or quit job; respondent fired, laid off, or quit job; respondent retired; respondent robbed or attacked. Events during the last five years were counted and the actual range was from 1 (for no events) to 9 ( 8 events). ( $M=3.63$ and $S D=1.58$.) Like other Holmes and Rahe derivatives, this measure assumes that all change is stressful despite evidence that some changes have positive impacts for certain persons and may not fully represent the stressful life changes that the elderly encounter (Whitbourne, 1985). Nevertheless, it is a reasonable control for possible differences in stressful life events between our comparison groups.

Health status was measured by the number of 14 common health problems diagnosed by a doctor within the last five years. It was based on the Cornell Medical Index (Brodman, Erdmann, Lorge and Wolff, 1960) and the OARS Multidimensional Functional Assessment Questionnaire (Center for the Study of Aging and Human Development, 1975). The problems were: stomach or digestion problems; arthritis or rheumatism; ulcers; cancer; hypertension or "high blood pressure"; diabetes or "sugar" or hypoglycemia; liver problem; kidney problem; stroke; blood circulation problems or "hardening of the arteries"; heart trouble; lung problem or trouble breathing; serious eye problems, such as glaucoma or cataracts; and hearing loss. The number of problems was grouped into four categories to avoid skewing resulting from the small number of $S \mathrm{~s}$ 
with many health problems: Level $1=$ no health problems, Level $2=$ $1-2$, Level $3=3-4$, and Level $4=5$ or more problems. $(M=2.25$ and $S D=.92$.

Income satisfaction was used to measure income because the data on actual income was based on household units, not individuals. Respondents rated themselves on a 7-point scale from very unsatisfied to very satisfied in response to the question, "How satisfied are you with your income?" $(M=5.15$ and $S D=1.92$. $)$

The age of the subjects ranged from 50 to 90 , with $M=68.0$ and $S D=9.82$.

\section{STATISTICAL APPROACH}

To estimate the generalized beneficial main effects of social support coverage on well-being, separate multiple regressions on each measure of well-being were run for each subgroup, controlling for life events, health problems, income satisfaction, and age. To test the buffering hypothesis that social support would have stronger effects in women exposed to more stress, the unstandardized regression coefficients for each of the well-being measures on social support coverage were compared for married women and widows and for recent and longer-term widows, using the $t$-statistic (Kmenta, 1971).

\section{RESULTS}

\section{DESCRIPTION OF THE GROUPS}

All the significant subgroups differences on the well-being measures were consistent with our characterization of the relative stress levels of the subgroups. Widows were less happy than the married women $(M=2.08$ versus $2.23, t=-2.14, d f=293, p<.05)$ and recent widows experienced more negative affect in the last few weeks than had longer-term widows $(M=2.62$ versus $1.96, t=2.70, d f=142, p<.01)$. None of the other subgroup comparisons for the well-being measures was significant.

The significant subgroup differences on the control variables supported their use as controls. They also indicated that, in addition 
to stress linked to bereavement grief, widows were exposed to more other sources of stress than were married women. Widows were older than women in their first marriages $(M=71.9$ versus $64.5, t=7.09$, $p<.001, d f=293)$ and widows reported more health problems $(M=$ 2.38 versus $2.12, t=2.40, p<.01, d f=293$ ) and less satisfaction with income $(M=4.90$ versus 5.36, $t=-2.08, p<.05, d f=293)$ than did married women. But widows and married women did not differ in the number of life events in the last five years.

Similarly, in addition to the higher level of bereavement grief assumed to differentiate the more recent widows from the longerterm ones, recent widows were also found to be in more stressful situations in other ways. Recent widows were significantly less satisfied with their incomes $(M=4.43$ versus $5.24, t=-2.40, d f=142$, $p<.01)$ and had experienced more life events in the last five years than had the long-term widows $(M=4.62$ versus $3.11, t=6.95, d f=$ $142, p<.001)$. On the other hand, recent widows were significantly younger than the longer-term widows $(M=68.67$ versus $74.24, t=$ $3.88, d f=142, p<.001)$, and health problems did not differentiate these groups.

Social support coverage did not differ significantly for widows and married women $(M=3.28$ versus 3.42$)$ or for recent and longer-term widows $(M=3.38$ versus 3.20$)$.

\section{SIMPLE RELATIONSHIPS AMONG VARIABLES}

Tables 1 and 2, respectively, show the correlations among the variables for widows and married women and for recent and longerterm widows. As in prior research (Stull, 1987), the measures of well-being were only moderately intercorrelated (.22 to .51$)$, although nearly all the correlations were significant and all were in the expected direction.

Most of the significant relationships between well-being and the control variables were similar for the subgroups: Happiness was correlated with income satisfaction in all four subgroups; positive affect was correlated with income satisfaction in all subgroups except the more recent widows; and negative affect was associated with more life events and younger ages in both widows and married women. Some of the control variables were significantly related to certain of the well-being measures in only one of the subgroups: Negative affect was inversely related to income satisfaction only for widows and 
TABLE 1

Correlations Among Variables for Widows and Married Women

\begin{tabular}{|c|c|c|c|c|c|c|c|c|}
\hline & $\begin{array}{l}\text { Life } \\
\text { Events }\end{array}$ & $\begin{array}{l}\text { Income } \\
\text { Satis- } \\
\text { faction }\end{array}$ & $\begin{array}{l}\text { Health } \\
\text { Problems }\end{array}$ & Age & $\begin{array}{l}\text { Social } \\
\text { Support }\end{array}$ & $\begin{array}{l}\text { Happi- } \\
\text { ness }\end{array}$ & $\begin{array}{l}\text { Posi- } \\
\text { tive } \\
\text { Affect }\end{array}$ & $\begin{array}{l}\text { Nega- } \\
\text { tive } \\
\text { Affect }\end{array}$ \\
\hline Events & 1.00 & $-.31 * *$ & .02 & $-.19 *$ & .04 & -.01 & .05 & $.17^{*}$ \\
\hline Income & $-.17^{*}$ & 1.00 & -.01 & $.26 * *$ & -.07 & $.35 * *$ & $.17^{*}$ & $-.20 *$ \\
\hline Health & .05 & -.09 & 1.00 & $.18^{*}$ & .07 & .03 & -.05 & .01 \\
\hline Age & $-.29 * *$ & .09 & $.23 * *$ & 1.00 & -.16 & .14 & -.10 & $-.25^{* *}$ \\
\hline $\begin{array}{l}\text { Support } \\
\text { Happi- }\end{array}$ & .05 & .13 & .02 & -.11 & 1.00 & .01 & .06 & $.18 *$ \\
\hline $\begin{array}{l}\text { ness } \\
\text { Pos. }\end{array}$ & -.11 & $.20 *$ & -.12 & .12 & .13 & 1.00 & $.18^{*}$ & $-.35 * *$ \\
\hline $\begin{array}{l}\text { Affect } \\
\text { Neg. }\end{array}$ & $.21 *$ & $.16^{*}$ & -.04 & -.10 & .11 & $.26 * *$ & 1.00 & $-.27 * *$ \\
\hline Affect & $.29 * *$ & -.07 & .06 & $-.20^{*}$ & -.04 & $-.27 * *$ & -.10 & 1.00 \\
\hline
\end{tabular}

NOTE: Values above the diagonal are for widows $(N=151)$; those below the diagonal are for married women $(N=144)$.

$* p<.05 ; * * p<.01$.

positive affect was directly associated with life events only for married women. In general, the relationships among the control variables were as expected and similar for the widows and married women, but these correlations differed in a number of respects for recent and longer-term widows.

Surprisingly, there were no significant correlations between social support coverage and the control variables. Social support showed only two significant correlations with well-being and each was contrary to the view of social support as ameliorating distress or enhancing positive emotions: More complete social support coverage was associated with more negative affect for the total group of widows and with less happiness for the more recent widows.

\section{MULTIPLE REGRESSIONS PREDICTING WELL-BEING}

The hypothesis that social support coverage would have a beneficial main effect in each subgroup is tested in the multiple 
TABLE 2

Correlations Among Variables for

Recent Widows and Long-Term Widows

\begin{tabular}{|c|c|c|c|c|c|c|c|c|}
\hline & $\begin{array}{l}\text { Life } \\
\text { Events }\end{array}$ & $\begin{array}{l}\text { Income } \\
\text { Satis- } \\
\text { faction }\end{array}$ & $\begin{array}{l}\text { Health } \\
\text { Problems }\end{array}$ & Age & $\begin{array}{l}\text { Social } \\
\text { Support }\end{array}$ & $\begin{array}{l}\text { Happi- } \\
\text { ness }\end{array}$ & $\begin{array}{l}\text { Posi- } \\
\text { tive } \\
\text { Affect }\end{array}$ & $\begin{array}{l}\text { Nega- } \\
\text { tive } \\
\text { Affect }\end{array}$ \\
\hline Events & 1.00 & -.21 & .00 & -.07 & .12 & -.15 & .07 & -.09 \\
\hline Income & $-.29 * *$ & 1.00 & $.26 *$ & $.27^{*}$ & -.24 & $.37 * *$ & .10 & -.19 \\
\hline Health & -.14 & $-.26^{*}$ & 1.00 & .22 & .06 & -.06 & .03 & -.04 \\
\hline Age & -.01 & .15 & .11 & 1.00 & -.22 & .16 & .00 & -.29 \\
\hline $\begin{array}{l}\text { Support } \\
\text { Happi- }\end{array}$ & -.10 & .09 & .09 & -.09 & 1.00 & $-.28 *$ & -.09 & .27 \\
\hline $\begin{array}{l}\text { ness } \\
\text { Pos. }\end{array}$ & -.20 & $.37 * *$ & .10 & .16 & .19 & 1.00 & .12 & $-.51 * *$ \\
\hline $\begin{array}{l}\text { Affect } \\
\text { eg. }\end{array}$ & .03 & $.23 *$ & -.09 & -.17 & .14 & $.22 *$ & 1.00 & $-.27 *$ \\
\hline Affect & .26 & -.14 & .10 & -.07 & .07 & $-.23 *$ & $-.31 * *$ & 1.00 \\
\hline
\end{tabular}

NOTE: Values above the diagonal are for recent widows $(N=60)$; those below the diagonal are for long-term widows $(N=84)$.

$* p<.05 ; * * p<.01$.

regressions presented in Table 3, for negative affect, and in Table 4, for happiness and positive affect. The hypothesis received no support for negative affect or positive affect within any of the four subgroups. Negative affect was marginally associated $(p<.10)$ with social support coverage among widows, but the coefficient was positive indicating that widows with more complete support coverage experienced more negative affect; for married women the nonsignificant coefficient was in the opposite direction. Positive affect was not significantly related to social support within any of the four subgroups. The regressions on happiness showed only weak support for a main effect of social support: Happiness was marginally associated $(p<.10)$ with more social support coverage only among the married women.

The buffering effect of social support coverage on each dependent variable was estimated by testing the differences in the relevant regression coefficients for widows versus married women and for 
TABLE 3

Multiple Regressions Predicting Negative Affect

\begin{tabular}{|c|c|c|c|c|c|c|}
\hline \multirow[b]{2}{*}{ Variable } & \multicolumn{4}{|c|}{ Subgroup } & \multicolumn{2}{|c|}{ t-statistics for } \\
\hline & $\begin{array}{l}\text { A11 Widows } \\
(\underline{N}=144)\end{array}$ & $\begin{array}{l}\text { Married } \\
(\underline{N}=151)\end{array}$ & $\begin{array}{l}\text { Recent } \\
\text { Widows } \\
(n=60)\end{array}$ & $\begin{array}{l}\begin{array}{c}\text { Long- } \\
\text { Term } \\
\text { Widows } \\
(\underline{n}=84)\end{array} .\end{array}$ & $\begin{array}{c}\text { All widows } \\
\text { vs. } \\
\text { Married }\end{array}$ & $\begin{array}{c}\text { Recent } \\
\text { vs. } \\
\text { Long-Term } \\
\text { Widows }\end{array}$ \\
\hline Constant & 3.72 & 3.11 & 5.49 & 1.62 & -.35 & 1.60 \\
\hline $\begin{array}{l}\text { Life Events } \\
\text { Income }\end{array}$ & .09 & $.21 * * *$ & -.21 & $.22 * *$ & -1.09 & $-2.30 * *$ \\
\hline $\begin{array}{l}\text { Satisfaction } \\
\text { Health }\end{array}$ & -.09 & -.00 & -.09 & -.03 & -.92 & -.44 \\
\hline Problems & .04 & .14 & .05 & .07 & -.54 & -.06 \\
\hline $\begin{array}{l}\text { Age } \\
\text { Social }\end{array}$ & $-.03^{* *}$ & $-.02 *$ & $-.04 *$ & -.01 & -.28 & -1.25 \\
\hline Support & $.20^{*}$ & -.10 & .42 & .10 & $1.75^{*}$ & 1.22 \\
\hline Multiple $R$ & $.33 * * *$ & $.33 * * *$ & $.40^{*}$ & .30 & & \\
\hline $\begin{array}{l}\text { R-Square } \\
\text { Standard }\end{array}$ & .11 & .11 & .16 & .09 & & \\
\hline Error & 1.40 & 1.38 & 1.70 & 1.11 & & \\
\hline
\end{tabular}

NOTE: Entries are unstandardized coefficients.

${ }^{*} p<.10 ; * * p<.05 ; * * * p<.01$.

recent versus longer-term widows. Certain differences were found, but they did not support the view of social support coverage as a buffer. Instead of social support coverage being more strongly related to less distress and to positive emotions in the subgroups exposed to more bereavement stress, social support tended to be associated with more distress and less happiness in those groups. Specifically, the difference in the regression coefficients for happiness on social support for recent widows and longer-term widows was significant and the signs of the coefficients indicated that recent widows with more social support coverage were less happy, whereas longer-term widows with more social support coverage were more happy. Similarly, the difference between the regression coefficients for negative affect on social support for widows and married women was at the marginal level $(p<.10)$ and, as noted above, widows with more 
TABLE 4

Multiple Regressions Predicting Happiness and Positive Affect

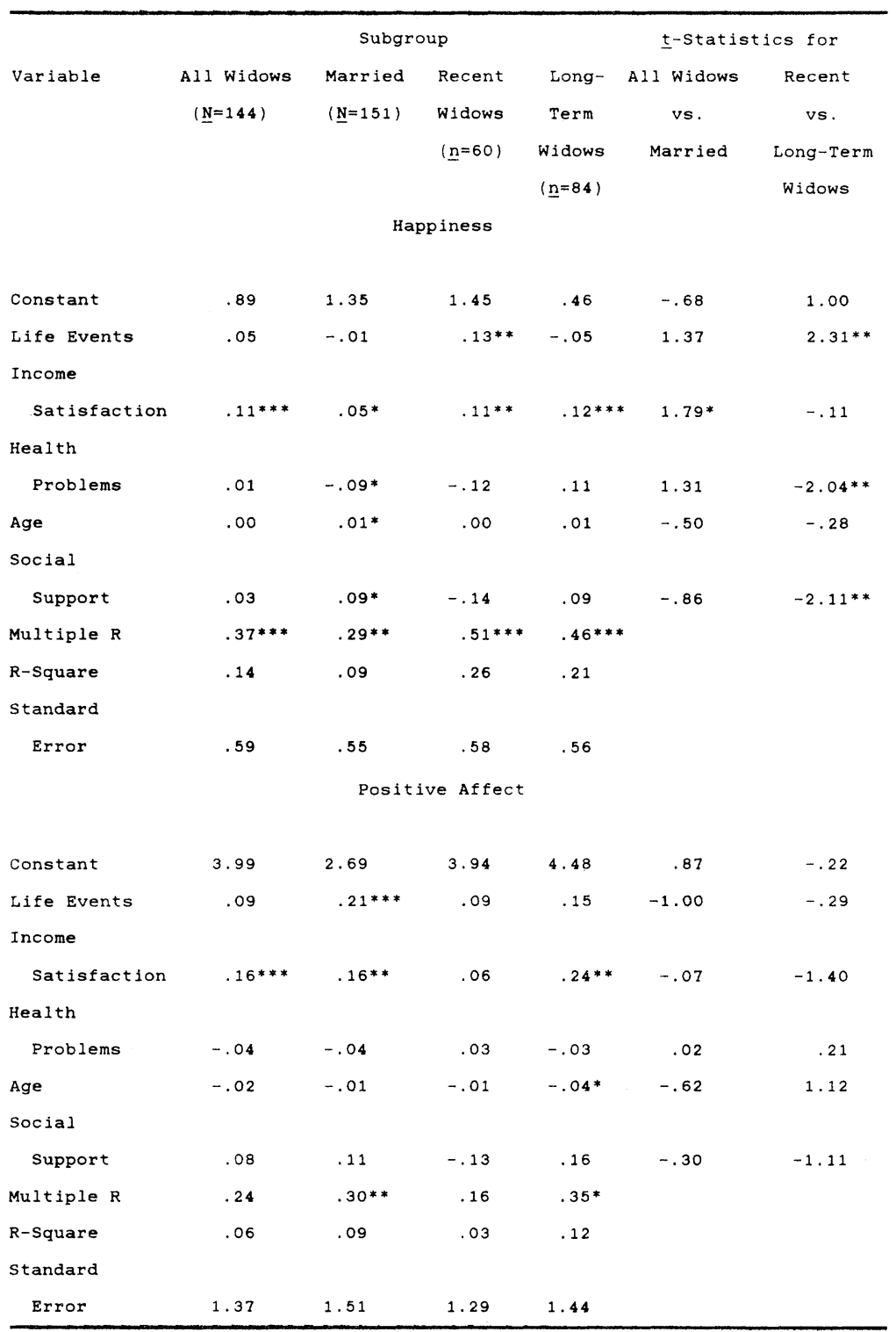

NOTE: Entries are unstandardized coefficients.

$* p<.10 ; * * p<.05 ; * * * p<.01$. 
social support tended to have more negative affect whereas married women with more social support tended to have less negative affect. There were no subgroup differences in the regression coefficients for positive affect on social support.

The regression coefficients for the dependent variables on the control variables are also shown in Tables 3 and 4 along with tests of the differences in coefficients in paired subgroups. The data are not directly relevant to the hypotheses, but are shown to provide some additional insight into the predictors of the three measures of well-being.

\section{DISCUSSION}

The hypothesis that social support coverage would have a generally beneficial main effect on the well-being of elderly woman was not supported. Two regression coefficients were at the marginal level $(p<.10)$, but only one was in the predicted direction (happiness for married women). Although generally beneficial effects of social support for the well-being of the elderly have often been proposed, there is little evidence of this in our sample of relatively healthy women.

On the basis of a conception of support as a buffer against distress under conditions of high stress we had also hypothesized that social support coverage would be a stronger predictor of well-being for elderly widows than for married women, and for more recent than for longer-term widows. These subgroups were assumed to differ in bereavement-related stress and the data on the control variables also showed certain other types of stress as more common among women widowed at age 50 or later than among elderly women in their first marriages, and among those widowed within the last five years than for longer-term widows.

The tests of the differences in the regression coefficients for social support coverage in the relevant subgroups did not, however, support the buffering hypothesis. Although the relationship between social support coverage and certain of the well-being measures differed for widows and married women, and for more and less recent widows, these differences were not those hypothesized: Social support coverage tended to be associated with the presence of negative affect among the total group of widows and with its absence among women 
in first marriages and, similarly, social support coverage was associated with the the absence of happiness among recent widows and its presence among longer-term widows. Thus support does seem to function in distinctive ways for widows and elderly married women, but it does not seem to be more important for widows than for married women.

These surprising findings raise several methodological and theoretical issues. Although the theory about social support as a buffer of stress from which we developed our hypotheses assumes that social support influences well-being, it is also possible that the presence of stress and its effects on well-being effect the availability of social support and that social support and well-being each influence the other (Turner, 1981; Wheaton, 1985). In our cross-sectional study we cannot determine the direction of any causal relationship between social support and well-being, although the regression models were set up as if the effects were from social support to well-being. It seems important, therefore, to consider the additional hypothesis that the well-being and other characteristics of persons effect the kind and amount of social support received. This leads to the question of how persons elicit support from others, a relatively neglected topic (Jung, 1987; Kessler et al., 1985).

People can get social support mainly in two ways: (1) by being outgoing and happy, and (2) by expressing depression and neediness. Married women and long-term widows who have supporters to turn to for most psychological needs may be garnering support because people enjoy being with and helping them; the availability of social supporters may then further enhance their well-being.

On the other hand, widows, and especially recent ones, may garner supporters because they have problems. These elderly widows were on average older, less satisfied with their income, less healthy, and felt less happy than the married women. Recent widows were less satisfied with their incomes, had experienced more life events in recent years, and had more negative emotions in the last few weeks than did longer-term widows. Potential supporters may recognize and respond to these profiles. This explanation is consistent with Mutran and Reitzes's (1984) study, which suggested that negative self-feeling of elderly widowed parents gathers adult children's support. Those widows with the most distress may thus garner more social support than those with less distress, resulting in a positive 
association between distress and social support. Further, when social supporters respond to severe distress their assistance may have only modest beneficial effects, which could only be discerned by tracking intraindividual changes in distress over time.

Additionally, there may be times when support elicited by the expression of distress has negative consequences for well-being; evidence is only beginning to accumulate on these conditions (Antonucci, 1985; Kessler et al., 1985; Rock, 1984). Recent studies of widows and the elderly suggest that some behaviors that are intended to be supportive, some supporters, or excessive amounts of support may provoke rather than reduce distress (Arling, 1987; Beck, 1987). Too much support may reduce one's sense of control or make the recipient feel overly dependent, an issue that may be crucial for the elderly (Krause, 1987). Receiving social support may also threaten the self-esteem of the recipient (Silverman, 1986).

Additionally, some support may be insensitive to the needs of the recipient. Supporters often encourage troubled persons to look on the bright side of things, which may be experienced by the recipients as minimizing their distress and indicating that they are behaving inappropriately (Jung, 1987). This could be a problem for widows if their network members underestimate the time it takes for them to overcome their grief, which sometimes persists in serious form for many years (Lund, Dimond, and Caserta, 1985-86). Lack of appreciation of their continued grief may be the reason emotional support from other widows or single friends has been found to have a positive effect on well-being, whereas support from married friends sometimes has negative consequences (Bankoff, 1981).

Social exchange theory identifies lack of reciprocity as another condition under which social support might have negative consequences (Antonucci, 1985). The importance of reciprocity is also suggested by Beckman's (1981) finding that elderly parents' perception that they provided support to their children is significantly related with their well-being. More complete social support coverage may have positive effects for married women, and for longer-term widows, because they have the economic and psychic resources to return the support they receive. Additionally, reciprocity may be more easily attained with a spouse, especially in long-term marriages, than with other relatives or friends, again making it more likely that the support that married women receive is reciprocated. Long-term 
widows may have had sufficient time to develop a history of reciprocal exchanges with new friends or relatives, whereas recent widows would be less likely to do so.

These interpretations are only tentative, given the nature of the data. Longitudinal data are needed to help unravel the causal directions of correlations between social support coverage and wellbeing. Data on the ways in which social support is given, and by whom, are needed to evaluate the causes of any negative effects of social support.

Another limitation on our conclusions is that the Social Support Coverage Index was based on reports of availability of supporters without information on whether social supporters were actually used and whether they met respondents' needs. This approach is consistent with evidence that perceptions about the accessibility of support, but not the actual use of social support, buffers stress (Cohen and Hoberman, 1983). The results suggest that for widows the perception that supporters are available to assist in major areas of need should not be equated with the perception that the support available is helpful. Further efforts to develop a measure of adequacy of support that is not confounded with outcome measures would be valuable.

Although, as expected, the significant relationships indicated that happiness and negative affect were associated with social support in consistent ways, not all of the relationships with these measures were significant. Additionally, positive affect was not related to social support in any subgroup. These results are consistent with Stull's (1987) conclusion that the content of the items in the Bradburn positive and negative affect balance scales are not parallel; he suggests that the positive items concern level of engagement, whereas the negative ones concern unpleasant emotions. Future research on stress and social support needs to clarify the conceptualization and measurement of well-being.

Some of the findings and conclusions are relevant to the provision of appropriate services to widows. The possibility that some widows may elicit social support by expressing their distress may be important for clinicians to assess. Under these circumstances clinicians might try to undo "unhappy people's unhappy role" by assisting them to learn positive ways to develop support systems. For example, widows might be encouraged to participate in social organizations in which they can provide support to others and develop a sense of control. This may be another reason that mutual support groups such 
as Widow-to-Widow groups are beneficial (Silverman, 1986). Clinicians might also assist potential supporters of widows in offering support that is sensitive to the needs of the widow, such as acknowledging the possibility that grief may extend over a long period. In these ways widows and their social supporters may be helped to elicit and provide social support under circumstances that will enhance the well-being of widows.

\section{REFERENCES}

Antonucci, Toni C. 1985. "Personal Characteristics, Social Support, and Social Behavior." Pp. 94-128 in Handbook of Aging and the Social Sciences, edited by Robert H. Binstoch and Ethel Shanas. New York: Van Nostrand Reinhold.

Arling, Greg. 1987. "Strain, Social Support, and Distress in Old Age." Journal of Gerontology 42(1):107-113.

Bankoff, Elizabeth A. 1981. "Effects of Friendship Support on the Psychological Well-Being of Widows." Pp. 109-139 in Research in the Interweave of Social Roles: Friendship, Vol. 2, edited by Helena Z. Lopata and David Maines. Greenwich: JAI.

1983. "Social Support and Adaptation to Widowhood." Journal of Marriage and the Family 45(4):827-839.

Beck, Rubye W. 1987. "Differential Responses to Social Support in a Sample of Widowed Men and Women." Paper presented at the Gerontological Society of America, Washington, DC, November.

Beckman, Linda J. 1981. "Effects of Social Interaction and Children's Relative Inputs on Older Women's Psychological Well-Being." Journal of Personality and Social Psychology 41(6):1075-1086.

Bock, Wilbur E. and Irving L. Webber. 1972. "Suicide Among the Elderly: Isolating Widowhood and Mitigating Alternatives." Journal of Marriage and the Family 34(1):24-31.

Bradburn, Norman. 1969. The Structure of Psychological Well-Being. Chicago: Aldine.

Brodman, Keave, Albert J. Erdmann, Jr., Irving Lorge, and Harold G. Wolff. 1960. The Cornell Medical Index: Health Questionnaire Manual. Ithaca, NY: Cornell University Medical College.

Center for the Study of Aging and Human Development. 1975. Multidimensional Functional Assessment: The OARS Methodology (1st edition). Durham, NC: Center for the Study of Aging and Human Development, Duke University.

Cohen, Sheldon and Harry M. Hoberman. 1983. "Positive Events and Social Supports As Buffers of Life Change Stress." Journal of Applied Social Psychology 13(2):99-125.

___ and Thomas Wills. 1985. "Stress, Social Support, and the Buffering Hypothesis." Psychological Bulletin 98(2):310-357. 
Dimond, Margaret, Dale A. Lund, and Michael S. Caserta. 1987. "The Role of Social Support in the First Two Years of Bereavement in an Elderly Sample." Gerontologist 27(5):599-604.

Fengler, Alfred P., L. Nicholas Danigelis, and Armin Grams. 1982. "Marital Status and Life Satisfaction Among the Elderly." International Journal of Sociology of the Family 12:63-76.

Heinemann, Gloria D. 1983. "Family Involvement and Social Support for Widowed Process." Pp. 127-148 in Family Relationships in Later Life, edited by Timothy H. Brubaker. Beverly Hills, CA: Sage.

Holmes, Thomas H. and Richard H. Rahe. 1967. "The Social Readjustment Rating Scale." Journal of Psychometrics Research 11:213-218.

House, James S. and Robert L. Kahn. 1985. "Measures and Concepts of Social Support."Pp. 83-108 in Social Support and Health, edited by Sheldon Cohen and Leonard Syme. New York: Academic Press.

Jung, John. 1987. “Toward a Social Psychology of Social Support." Basic and Applied Social Psychology 81:57-83.

Kahn, Robert L. and Toni C. Antonucci. 1985. "Support of Elderly: Family/Friends/ Professionals." Final report for the National Institute on Aging of the Department of Health and Human Services.

Kessler, Ronald C., Richard H. Price, and Camille B. Wortman. 1985. "Social Factors in Psychopathology: Stress, Social Support, and Coping Process." Annual Review of Psychology 36:531-572.

Kmenta, Jan. 1971. Elements of Econometrics. New York: Macmillan.

Kohen, Janet A. 1983. "Old But Not Alone: Informal Social Supports Among the Elderly by Marital Status and Sex." Gerontologist 23(1):57-63.

Krause, Neal. 1987. "Understanding the Stress Process: Linking Social Support with Locus of Control Beliefs." Journal of Gerontology 42:589-593.

Larson, Reed. 1978. "Thirty Years of Research on the Subjective Well-Being of Older Americans." Journal of Gerontology 33:109-125.

Liang, Jersey, Louis Dvorkin, Eva Kahana, and Florence Mazian. 1980. "Social Integration and Morale: A Reexamination." Journal of Gerontology 35(5):746-757.

Lopata, Helena Z. 1979. Women as Widows: Support Systems. New York: Elsevier.

Lowenthal, Marjorie and Clayton Havens. 1968. "Interaction and Isolation: Intimacy As a Critical Variable." American Sociological Review 33:20-30.

Lund, Dale, Margaret F. Dimond, and Michael S. Caserta. 1985-86. "Identifying Elderly with Coping Difficulties After Two Years of Bereavement." OMEGA: Journal of Death and Dying 16(3):213-224.

Morgan, Leslie A. 1976. “A Re-examination of Widowhood and Morale." Journal of Gerontology 31(6):687-695.

___1984. "Changes in Family Interaction Following Widowhood." Journal of Marriage and the Family 46(2):323-331.

Mutran, Elizabeth and Donald C. Reitzes. 1984. "Intergenerational Support Activities and Well-Being Among the Elderly: A Convergence of Exchange and Symbolic Interaction Perspectives." American Sociological Review 49:117-130.

Pilisuk, Marc and Meredith Minkler. 1980. "Supportive Networks: Life Ties for the Elderly." Journal of Social Issues 36(2):95-116. 
Rock, Karen S. 1984. "The Negative Side of Social Interaction: Impact on Psychological Well-Being." Journal of Personality and Social Psychology 46(5): 1097-1108.

Silverman, Phyllis R. 1986. Widow to Widow. New York: Springer.

Stroebe, Wolfgang and Margaret S. Stroebe. 1987. Bereavement and Health. Cambridge: Cambridge University Press.

Stull, Donald E. 1987. "Conceptualization and Measurement of Well-Being."Pp. 55-90 in Critical Issues in Aging Policy, edited by Edgar F. Borgatta and Rhonda J. V. Montgomery. Newbury Park, CA: Sage.

Thompson, Larry W., Dolores E. Gallagher, James N. Breckenridge, and James A. Peterson. 1984. "Effects of Bereavement on Self-Perceptions of Physical Health in Elderly Widow and Widower." Journal of Gerontology 39(3):309-314.

Turner, Jay R. 1981. "Social Support As a Contingency in Psychological Well-Being." Journal of Health and Social Behavior 22:357-367.

1983. "Direct, Indirect and Moderating Effects of Social Support Upon the Psychological Distress and Associated Conditions." Pp. 105-155 in Psychological Stress: Trends in Theory and Research, edited by Howard B. Kaplan. New York: Academic Press.

Vachon, Mary L. S., Joy W. Rogers, Alan Lyall, Wilhelm J. Lancee, Adrienne R. Sheldon, and Stanley J. J. Freeman. 1982. "Predictors and Correlates of Adaptation to Conjugal Bereavement." American Journal of Psychiatry 139(8):998-1002.

Veroff, Joseph, Elizabeth Douvan, and Richard A. Kulka. 1981. The Inner America. New York: Basic Books.

Wheaton, Blair. 1985. "Models for the Stress-Buffering Functions of Coping Resources." Journal of Health and Social Behavior 26: 352-364.

Whitebourne, Susan K. 1985. "The Psychological Construction of the Life Span." Pp. 595-618 in Handbook of the Psychology of Aging, edited by James E. Birren and K. Warner Schaie. New York: Von Nostrand Reinhold. 